\title{
RESIDUAL STRESS IN TI6AL4V OBJECTS PRODUCED BY DIRECT METAL LASER SINTERING\#
}

\author{
I. van Zyl ${ }^{1}$, I. Yadroitsava ${ }^{1 *}$, I. Yadroitsev ${ }^{1}$
}

\section{ARTICLE INFO}

Article details

Submitted by authors 12 Jan 2016

Accepted for publication 1 Aug 2016

Available online $\quad 6$ Dec 2016

\# This is an extended version of a paper presented at the $16^{\text {th }}$ International Conference of the Rapid Product Development Association of South Africa (RAPDASA), held from 4 to 6 November 2015 in Pretoria, South Africa

\section{Contact details}

* Corresponding author iyadroitsava@cut.ac.za

Author affiliations

1 Department of Mechanical and Mechatronic Engineering, Central University of Technology, Free State, South Africa

\section{DOI}

http://dx.doi.org/10.7166/27-4-1468
ABSTRACT

Direct Metal Laser Sintering produces 3D objects using a layer-bylayer method in which powder is deposited in thin layers. Laser beam scans over the powder fusing powder particles as well as the previous layer. High-concentration of laser energy input leads to high thermal gradients which induce residual stress within the asbuilt parts. Ti6Al4V (ELI) samples have been manufactured by EOSINT M280 system at prescribed by EOS process-parameters. Residual stresses were measured by XRD method. Microstructure, values and directions of principal stresses inTi6Al4V DMLS samples were analysed.

\section{OPSOMMING}

Direkte laser metaal sintering vervaardig driedimensionele voorwerpe deur gebruik van 'n laag-op-laag metode waar poeier in dun lae gedeponeer word. Die laser straal skandeer die poeier en smelt die deeltjies en die vorige laag aan mekaar. Die hoë konsentrasie van laser energie inset lei na hoë termiese gradiënte wat veroorsaak dat daar res-spanning in die onderdele is. Tot op hede is monsters vervaardig deur die EOSINT M280 sisteem teen voorgeskrewe EOS proses paremeters vir Ti6Al4V (ELI) poeier. Argon is gebruik as die beskermingsatmosfeer. Res-spanning is gemeet met die XRD (bestraling diffraksie) metode. Mikrostruktuur, waardes en rigting van hoof spanning in Ti6Al4V monsters is ontleed.

Additive manufacturing $(\mathrm{AM})$ is a relatively new manufacturing technology. From its development in the 1980 s up to the present day, $A M$ has developed at a rapid rate. Direct metal laser sintering (DMLS) is a type of AM that produces objects from metal powder deposited in a thin layer by selective laser scanning. The laser beam scans over the powder, thus melting the powder particles and the previous layer. Sequentially, track-by-track, layer-by-layer, a 3D part is sintered. DMLS can produce fully dense parts of complex geometry with internal structures and also light-weight lattice structures. This technique opens up new avenues, especially in the automotive, aerospace, and medical fields, where the unique design is required.

Ti6Al4V alloy is a low-density, high-strength, extraordinarily corrosion-resistant material that is also biocompatible. Ti6Al4V is not only ideal for medical applications, but it is also one of the main alloys incorporated in aerospace applications due to its high strength-to-weight ratio. Ti6Al4V alloy is $\alpha-\beta$ titanium heat-treatable alloy, which makes it more attractive due to its versatility [3]. The Centre for Rapid Prototyping and Manufacturing at the Central University of Technology in the Free State, South Africa, specialises in producing implants from Ti6Al4V (ELI) powder.

Modern DMLS systems such as EOSINT M280 system from EOS GmbH use fibre lasers with high power densities. For a laser power of $200 \mathrm{~W}$ and a spot size of $80 \mu \mathrm{m}$, power density reaches $\sim 40 \mathrm{~kW} / \mathrm{mm}^{2}$. The concentrated heat input of the DMLS process leads to high thermal gradients that induce residual stress within the part. Knowledge about the values and directions of residual stress is of primary importance for manufacturing reliable DMLS parts. 
Residual stresses are the stresses that are locked in a solid material when it has obtained equilibrium; these stresses are in balance, with no external influences applied. The effects of residual stress may be either beneficial or detrimental, depending on the magnitude, sign, and distribution of the stress with respect to the load-induced stresses. Very commonly, residual stresses are detrimental, and there are many documented cases where these stresses were the main factor contributing to fatigue and other structural failures when the service stresses were superimposed on the already present residual stresses. The particularly insidious aspect of residual stress is that its presence generally goes unrecognised until after a malfunction or failure occurs [15]. Leuders et al. [8] studied fatigue resistance and crack growth performance in DMLS Ti6Al4V samples. They found that the main influencing factor on crack growth behaviour is the residual stress. Vrancken et al. [16] investigated residual stress in DMLS Ti6Al4V compact tension specimens produced at different building strategies ( $x z, z x$, and $x y$ direction). With the contour method, it was found that the residual stress is a major factor in the anisotropic behaviour of material produced by DMLS.

Generally, slight deformations will not affect the manufacturing, but significant warp (more than the thickness of the deposited powder layer) or the separation of the part from the support structures means that during deposition of a new powder layer, the blade or roller will touch the deformed parts, causing even greater deformation of the parts (Figure 1(a),(b)). In addition, the resulting vibration causes redistribution of the loose powder in the form of funnels (Figure 1(c)). Online monitoring with feedback is a vital task for the additive manufacturing technologies.

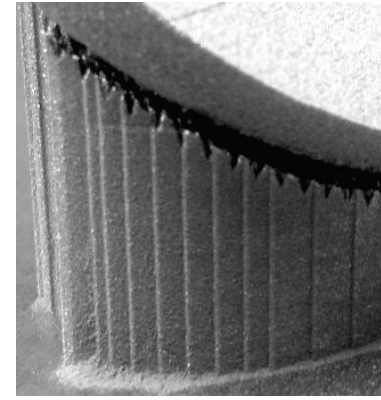

(a)

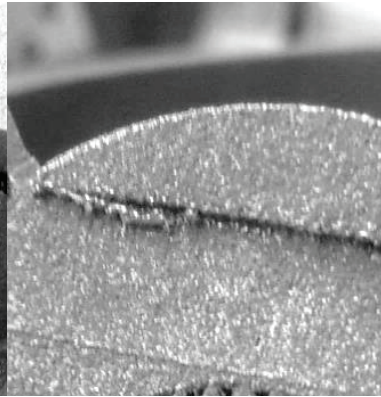

(b)

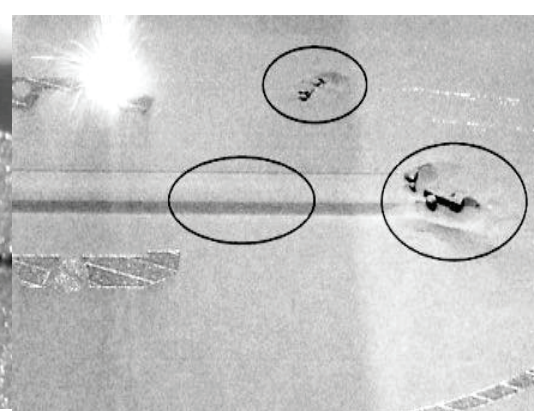

(c)

Figure 1: (a) Delamination from the support structures; (b) deformation of the part during manufacturing; and (c) redistribution of non-sintered powder due to vibration caused by direct contact of the blade with deformed fine parts of the objects during manufacturing

Sochalski-Kolbus et al. [13] indicate that different process-parameters and temperature-dependent properties of the materials lead to the fact that residual stress distributions in AM are not the same from material to material or from process to process. Most of the factors influencing the residual stress are either directly or indirectly related to the thermal gradients. Buchbinder et al. [1] investigated reducing distortion in DMLS by preheating during the manufacturing of aluminium components. They noted that, under preheating, lower temperature gradients cause lower residual stresses, but that lowered yield strength of the material at elevated temperature promotes plastic deformations.

Merselis et al. [9] found that residual stresses increased with the height of the samples. Tensile residual stresses within the samples were extremely large at the top surface and in the area of the interface between the substrate and sintered sample $[6,14]$. For the samples manufactured with support structures, tensile residual stresses near the surface (xy plane) were non-uniform in the specimen thickness, but for all samples, maximal residual stresses were in the top part of the specimens [2].

It was found that scanning strategies influence residual stresses in DMLS parts; random sector exposure (island strategy) had lower values of stresses than the samples manufactured by onescanning direction $[9,19]$, and longitudinal scanning led to the highest values of stresses [19]. Kruth et al. [7] suggested that the shorter scan tracks led to smaller temperature gradients due to the higher remnant of heat from the previous scan track. 
Residual stresses can be effectively relieved by heating during manufacturing and by stress-relieving heat treatment in a furnace after manufacturing [11]. Post-heat treatment reduced the stresses more than optimising the parameters for the island-scanning strategy [7]. Sochalski-Kolbus et al. [13] compared residual stress in DLMS and EBM samples. The assumption was made that some factors, such as preheating, larger hatching spacing, and slow cooling, cause lower residual stress in EBM specimens than in DMLS samples. It was indicated that the crystallographic texture can affect the macro-strain of AM objects; however, further work needs to be done to get a better quantitative measure of this effect.

\section{MATERIALS AND METHODS}

The Ti6Al4V (ELI) powder was the pre-alloyed gas-atomised powder. The chemical composition was as follows: $\mathrm{Ti}$ - balance, $\mathrm{Al}-6.31 \%, \mathrm{~V}-4.09 \%, \mathrm{O}-0.12 \%, \mathrm{~N}-0.009 \%, \mathrm{H}-0.003 \%, \mathrm{Fe}-0.20 \%$, and $\mathrm{C}$ $0.005 \%$ (weight \%). The equivalent diameters (by volume) of the powder particles were $d_{10}=13 \mu \mathrm{m}$, $d_{50}=23 \mu \mathrm{m}$, and $d_{90}=37 \mu \mathrm{m}$.

Ti6Al4V samples were produced by the EOSINT M280 system. A back-and-forth scanning by strips with the hatch distance of $100 \mu \mathrm{m}$ was applied for manufacturing specimens such as cubes and parallelepipeds. The substrate and powder materials were similar in chemical composition. Argon was used as the protective atmosphere.

The residual stress measurements were done with an X-ray diffractometer from ProtoXRD. The residual stresses were determined using the $\sin ^{2} \psi$ method. The lattice deformations of the Ti-a were determined using a CuKa radiation source. Scans were performed around a $\{213\}$ Bragg diffraction peak $\left(2 \theta \sim 139.69^{\circ}\right)$ at 9 tilting angles $\psi$ between -44.16 and $+44.16^{\circ}$. The residual stresses were calculated considering plan stress conditions using the X-ray elastic constants shown in Table 1. The electrolytic removal technique was used to determine in-depth residual stress distribution. Rotation of the scanning direction is the standard strategy incorporated by the EOS machine; principal stresses and their directions were analysed.

Table 1: Parameters used for the X-ray analysis

\begin{tabular}{|c|c|c|c|c|c|c|c|}
\hline $\begin{array}{c}\text { Test } \\
\text { material }\end{array}$ & $\begin{array}{c}\text { Collimator, } \\
\mathrm{mm}\end{array}$ & Wavelength, $\AA$ & Radiation & $\begin{array}{c}\text { Bragg angle } \\
2 \theta,\end{array}$ & $\mathrm{h} \mathrm{k} \mathrm{l}$ & $1 / 2 \mathrm{~S}_{2}, \mathrm{MPa}^{-1}$ & $-\mathrm{S}_{1}, \mathrm{MPa}^{-1}$ \\
\hline Ti a & 3 & 1.5418 & $\mathrm{Cu} \mathrm{Ka}$ & 139.69 & $\{213\}$ & $11.89 \times 10^{-6}$ & $2.83 \times 10^{-6}$ \\
\hline
\end{tabular}

\section{RESULTS AND DISCUSSION}

Ti6Al4V (ELI) DMLS samples were produced using the process parameters and strategy recommended by EOS for the $M 280$ machine. The last layers of the parts were rescanned twice, without stripes, at $90^{\circ}$ for each layer ('upskin' regime). The resulting surface was smooth, and the surface roughness was very low: $R a=4.6 \pm 0.45 \mu \mathrm{m}, R z=21.9 \pm 1.93 \mu \mathrm{m}$. All the samples that were produced had low levels of porosity.

Figure 2 shows optical microscope photos of etched cross-sections in the different planes of the sample $(x y z 35 \times 5 \times 20 \mathrm{~mm})$ built in the $z$ direction. A received martensitic $\alpha$ ' microstructure is typical for Ti6Al4V samples manufactured by DMLS [10]. In the $(x z)$ and $(y z)$ planes, columnar growth is observed; in the transverse direction $(x y)$, the bundles of columnar grains are seen. The microstructure of the DMLS samples differs from the microstructure of wrought Ti6Al4V alloy, since the cooling rates during DMLS reach $10^{5}-10^{6} \mathrm{~K} / \mathrm{s}$ (Figure 3 ).

The strain during cooling can be described as a superposition of elastic, thermal, and plastic properties, as well as a creep strain component. Numerical simulations showed that at a laser power density of $19.1 \mathrm{~kW} / \mathrm{mm}^{2}$ and a scanning speed of $1.2 \mathrm{~m} / \mathrm{s}$, the maximal temperature during the laser melting of Ti6Al4V alloy was approximately 3,000 K (Figure 3). The heat-affected zone and the molten pool had an elongated shape in the scanning direction. When the laser beam leaves the irradiated zone, the track begins to solidify and to cool down. Various layers of material cool at different rates (Figure 3); therefore contraction also occurs at different speeds. During laser melting, high compressive and tensile stresses are present under the front of the molten pool [17, 18]. As a result, deformations occur in the surrounding material and the solidifying track. 


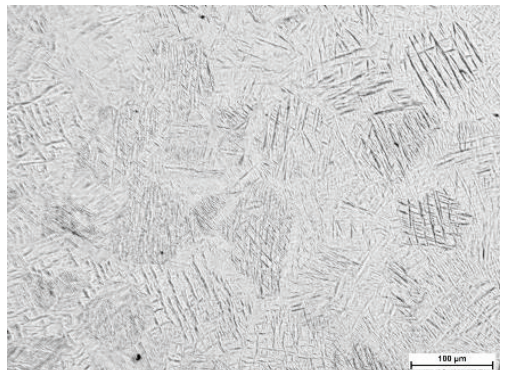

(a)

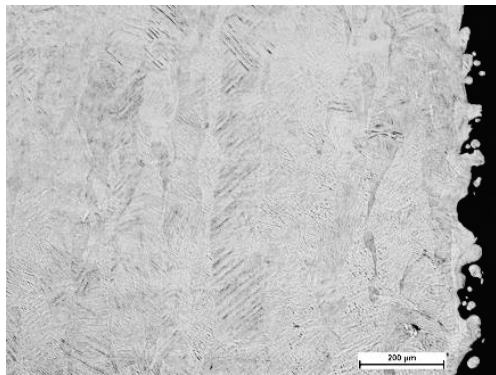

(b)

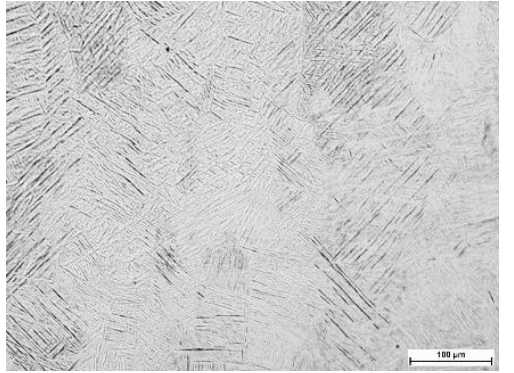

(c)

Figure 2: Microstructure of the sample from Ti6Al4V (ELI) powder at different cross-sections: (a) $x y$; (b) $y z$; and (c) $x z$ planes

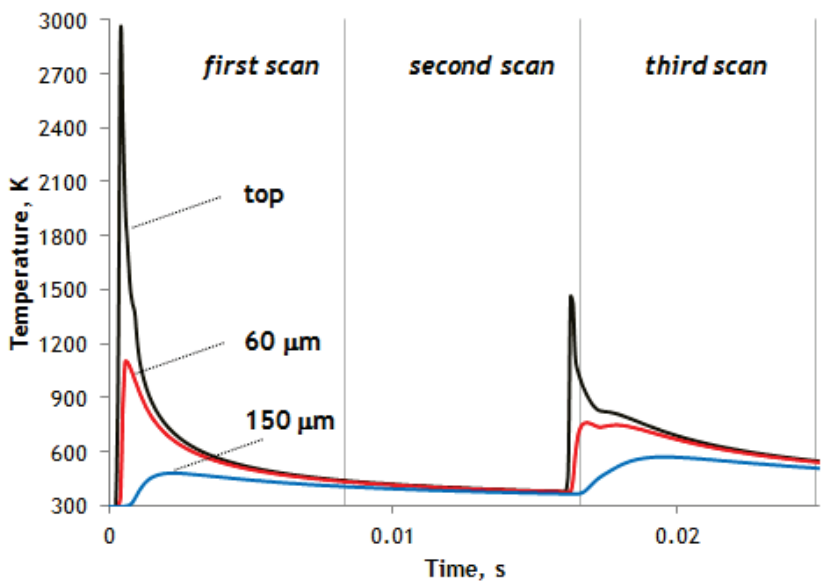

Figure 3: Temperature profiles (point $x=0.5 \mathrm{~mm}$, depth $z=0,60$, and $150 \mu \mathrm{m}$ ) during back-andforth laser scanning of the Ti6Al4V sample with length of $1 \mathrm{~cm}$, laser power density of $19.1 \mathrm{~kW} / \mathrm{mm}^{2}$, and scanning speed of $1.2 \mathrm{~m} / \mathrm{s}$

The delivering of powder, subsequent melting, and solidification lead to variations in the thickness of the next layers, the formation of pores, and the heating of adjacent layers, which can affect the residual stress value. The numerical simulation of residual stresses in the object, consisting of a large number of the tracks with a width of $100-150 \mu \mathrm{m}$ and layers of thickness near $30 \mu \mathrm{m}$, is a difficult and apparently unsolvable problem. It is important to understand the direction and the magnitude of the stress when scanning a certain material with certain process parameters.

For $1 \times 1 \mathrm{~cm}$ DMLS samples that adhered to the substrate, values of residual stresses near the surface measured in the central point of the surface varied significantly with the height (from $470-825 \mathrm{MPa}$ for the first principal stress and 225-420 MPa for the second principal stress, as shown in Figure 4). The first principal stresses near the surface were practically coaxial with the scanning direction. 


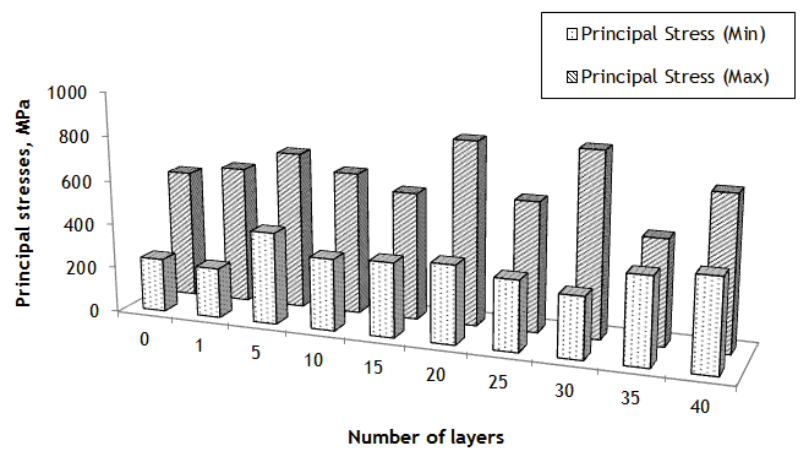

Figure 4: Principal stresses near the surface in $1 \times 1 \mathrm{~cm}$ square Ti6Al4V samples with 0-40 layers in height. Powder layer thickness is $30 \mu \mathrm{m}$.

Residual stresses were measured in the middle of the top surface of the cubes manufactured with or without support structures. For both cubes, the values of the maximal residual stress were similar to the mean residual stress received for the samples that were 10-40 layers in height. Residual stresses in the cube produced with supports were partially relieved by separation from the support structures during manufacturing (Figure 5 ).
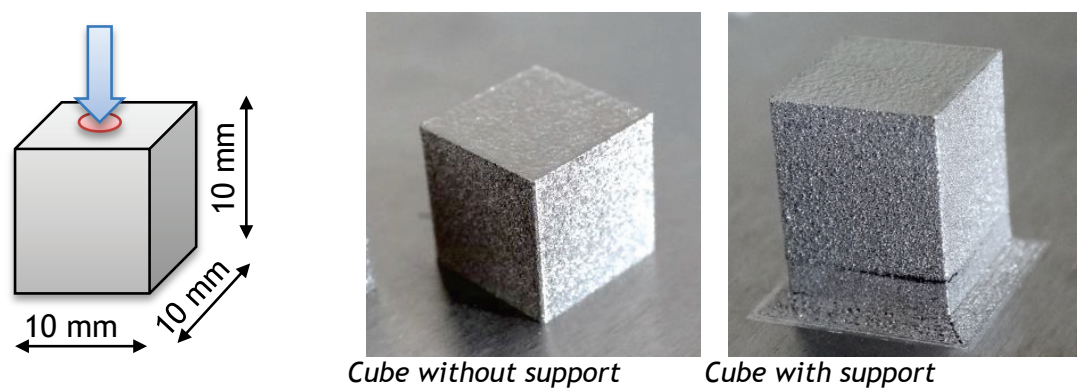

(a)

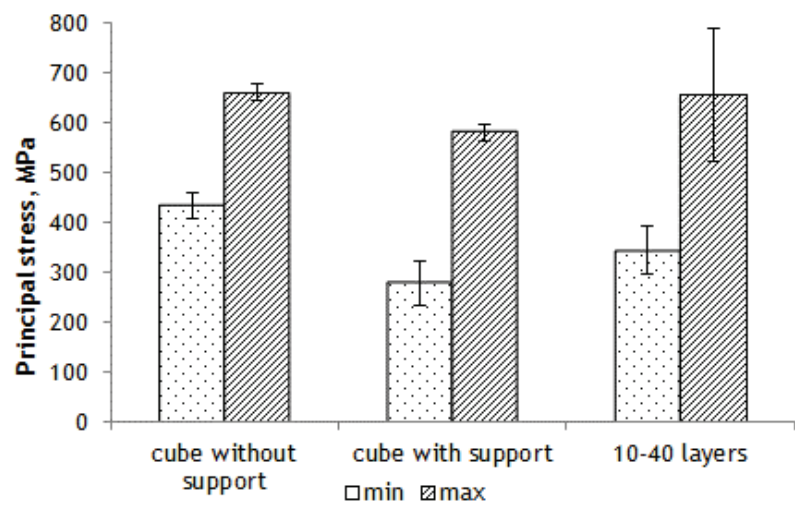

(b)

Figure 5: Principal residual stresses near the top surface of the Ti6Al4V samples

In the present work, residual stresses near the top surface in Ti6Al4V samples were tensile and high: 200-800 MPa. The high variability of residual stresses can be linked to the inhomogeneity of delivered powder layers, which leads to different strains during cooling. Deformations and the loss of metallurgical contact with the previous layers during manufacturing led to the re-distribution of stresses. A combination of high values of residual stresses in DMLS parts and imperfections, such as porosity or lack of fusion between layers/supports/substrate, can cause deformation and stress relaxation; it can affect the integrity of the part and its dimensions during manufacturing. Figure 6 illustrates how an imperfection of $0.005 \mathrm{~mm}^{3}$ (lack of metallurgical contact with the substrate) can influence the residual stress. Relaxation of the stresses caused partial separation of the 
$30 \times 10 \times 10 \mathrm{~mm}$ parallelepiped from the substrate, as shown in Figure 7. Residual stresses were lower in Point 3 near the detached part of the sample, which corresponds with Case 4 in Figure 6.

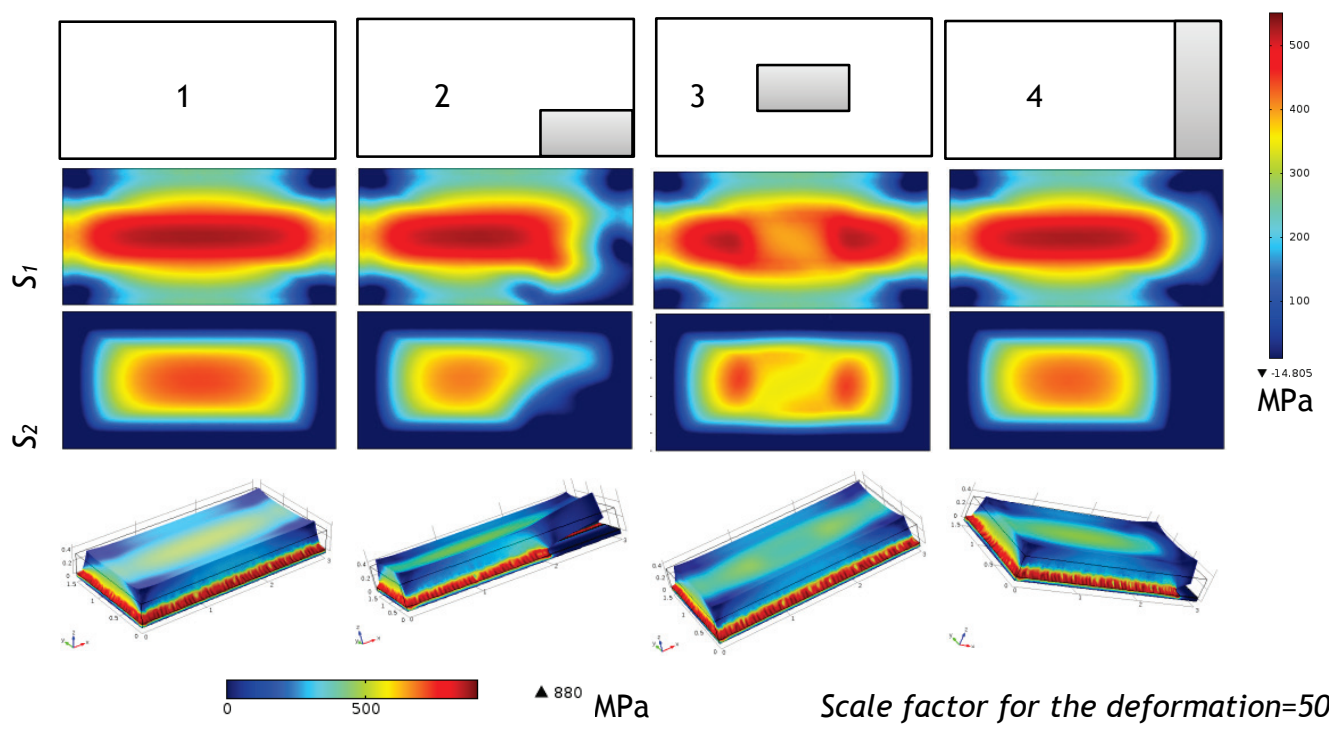

Figure 6: Residual stresses at the top surface in the parts $3 \times 1.5 \times 0.3 \mathrm{~mm}(x \times y \times z \mathrm{~mm})$ without/with imperfections. Initial stress $\sigma_{x x}=600 \mathrm{MPa}, \sigma_{y y}=900 \mathrm{MPa}, \sigma_{x y}=\sigma_{x z}=25 \mathrm{MPa}$

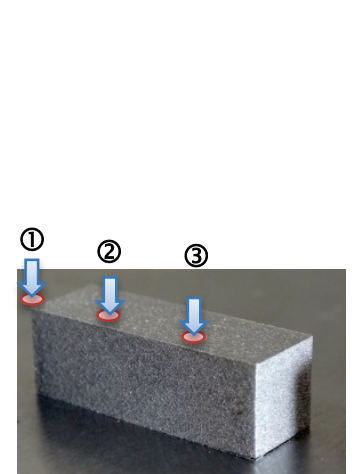

(a)

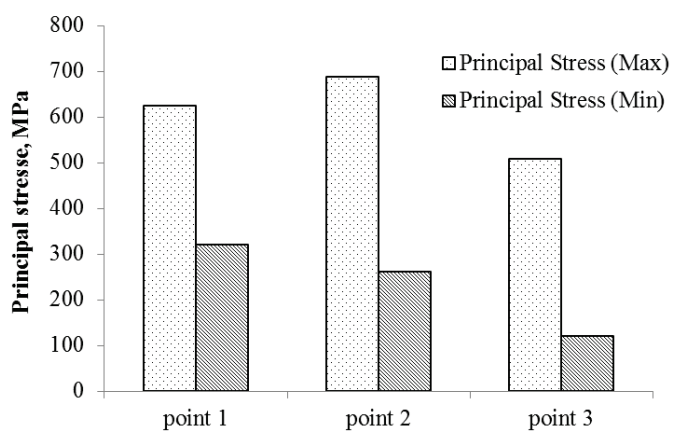

(b)

Figure 7: (a) DMLS Ti6Al4V (ELI) parallelepiped at the substrate, and (b) principal residual stresses in 3 points near the surface

Sources of uncertainty in residual stress measurements and the accuracy of calculations depend on elastic constants, non-linearity due to texture, stress gradients with depth, and micro-stresses due to plastic deformation or grain interactions $[4,5]$. Simonelli et al. [12] found that elastic moduli of as-built Ti6Al4V DMLS samples did not vary with build orientation, since the samples had a weak $\alpha$ ' (or $\alpha$ ) crystallographic texture. Residual stress depends not only on material properties, process parameters, powder-layer thickness, scanning strategy, preheating, etc., but also on the geometry of the samples and support structures. At selected process-parameters, the direction of the major stresses in Ti6Al4V (ELI) samples were coaxial with the scanning direction; this should be taken into account when choosing a scanning strategy for objects with complex shapes, the building strategy involving positioning of the part on the substrate; and also the definition of the support structures applied to the DMLS parts. During manufacturing, heat treatment is seen as the main way to reduce residual stresses in DMLS parts. 
The residual stresses in as-built Ti6Al4V samples, measured by the XRD method in the $x y$ plane, were biaxial tensile stresses. The major component was coaxial with the scanning direction. Before removal from the substrate, all DMLS samples, especially those with fine-structured features, must be heat-treated to avoid significant deformation. Determining the optimal conditions for different materials to relieve the residual stresses during manufacturing and to obtain acceptable performance properties of DMLS parts is a topic for further in-depth studies in DMLS.

\section{ACKNOWLEDGEMENTS}

This work is based on research supported by the South African Research Chairs Initiative of the Department of Science and Technology and the National Research Foundation of South Africa (Grant №97994), and the Collaborative Programme in Additive Manufacturing (Contract №CSIR-NLCCPAM-15-MOA-CUT-01). This work is benefited from the cooperation between the Central University of Technology, Free State and Nelson Mandela Metropolitan University (NMMU). Authors would like to acknowledge Director of eNtsa NMMU Prof. D. Hattingh for his help and wish to express their thanks to S. Grewar and R. Brown for performing the XRD measurements.

\section{REFERENCES}

[1] Buchbinder, D., Meiners, W., Pirch, N., Wissenbach, K. and Schrage, J. 2014. Investigation on reducing distortion by preheating during manufacture of aluminum components using selective laser melting, Journal of Laser Applications, 26(1), pp. 012004-1-10.

[2] Casavola, C., Campanelli, S.L. and Pappalettere, C. 2009. Preliminary investigation on distribution of residual stress generated by the selective laser melting process. The Journal of Strain Analysis for Engineering Design, 44(1), pp. 93-104.

[3] Donachie, M.J. 2000. Titanium: A technical guide, 2nd edition. Materials Park, Ohio: ASM International, Technology \& Engineering.

[4] Fitzpatrick, M.E., Fry, A.T., Holdway, P., Kandil, F.A., Shackleton, J. and Suominen, L. 2005. Determination of residual stresses by X-ray diffraction. A National Measurement Good Practice Guide, 52(2), p. 68.

[5] Fry, A.T. and Lord, J.D. 2009. Measuring residual stresses in stainless steel - Recent experiences within a VAMAS exercise. Powder Diffraction, 24(S1), pp. S41-S44.

[6] Furumoto, T., Ueda, T., Aziz, A., Sanusi, M., Hosokawa, A. and Tanaka, R. 2010. Study on reduction of residual stress induced during rapid tooling process: Influence of heating conditions on residual stress. Key Engineering Materials, 447-448, pp. 785-789.

[7] Kruth, J.-P., Deckers, J., Yasa, E. and Wauthle, R. 2012. Assessing and comparing influencing factors of residual stresses in selective laser melting using a novel analysis method. Proc IMechE Part B: J. Engineering Manufacture, $0(0)$, pp. 1-12.

[8] Leuders, S., Thöne, M., Riemer, A., Niendorf, T., Tröster, T., Richard, H.A. and Maier, H.J. 2013. On the mechanical behaviour of titanium alloy TiAl6V4 manufactured by selective laser melting: Fatigue resistance and crack growth performance. International Journal of Fatigue, 48, pp. 300-307.

[9] Mercelis, P. and Kruth, J.-P. 2006. Residual stresses in selective laser sintering and selective laser melting. Rapid Prototyping Journal, 12(5), pp. 254-265.

[10] Rafi, H.K., Karthik, N.V., Gong, H., Starr, T.L. and Stucker, B.E. 2013. Microstructures and mechanical properties of Ti6Al4V parts fabricated by selective laser melting and electron beam melting. Journal of Materials Engineering and Performance, 22(12), pp. 3873-3883.

[11] Shiomi, M., Osakada, K., Nakamura, K., Yamashita, T. and Abe, F. 2004. Residual stress within metallic model made by Selective Laser Melting process. CIRP Annals - Manufacturing Technology, 53(1), pp. 195198.

[12] Simonelli, M., Tse, Y.Y. and Tuck, C. 2014. Effect of the build orientation on the mechanical properties and fracture modes of SLM Ti-6Al-4V. Materials Science and Engineering, A616, pp. 1-11.

[13] Sochalski-Kolbus, L.M., Payzant, E.A., Cornwell, P.A., Watkins, T.R., Babu, S.S., Dehoff, R.R., Lorenz, M., Ovchinnikova, O. and Duty, C. 2015. Comparison of residual stresses in Inconel 718 simple parts made by Electron Beam Melting and Direct Laser Metal Sintering. Metallurgical and Materials Transactions, A, 46(3), pp. 1419-1432.

[14] Van Belle, L., Vansteenkiste, G. and Boyer, J.-C. 2012. Comparisons of numerical modelling of the Selective Laser Melting. Key Engineering Materials, 504, pp. 1067-1072.

[15] Vishay Measurements Group, Inc. 1993. Measurement of residual stresses by the hole-drilling strain-gage method. Tech Note TN-503-6. Vishay Measurements Group, Inc., Raleigh, NC.

[16] Vrancken, B., Cain, V., Knutsen, R. and Van Humbeeck, J. 2014. Residual stress via the contour method in compact tension specimens produced via selective laser melting. Scripta Materialia, 87, pp. 29-32.

[17] Yadroitsava, I., Grewar, S., Hattingh, D. and Yadroitsev, I. 2015. Residual stress in SLM Ti6Al4V alloy specimens. Materials Science Forum, 828-829, pp. 305-310. 
[18] Yadroitsev, I. and Yadroitsava, I. 2015. Evaluation of residual stress in stainless steel 316L and Ti6Al4V samples produced by selective laser melting. Virtual and Physical Prototyping, 10(2), pp. 67-76.

[19] Zaeh, M.F. and Branner, G. 2010. Investigations on residual stresses and deformations in selective laser melting. Production Engineering - Research and Development, 4(1), pp 35-45. 